\title{
KONVERGENSI ATMOSFER LAPISAN BAWAH DAN HUBUNGANNYA DENGAN HUJAN EKSTRIM (STUDI KASUS: BANJIR CIREBON 15 FEBRUARI 2017)
}

\author{
Low Level Atmospheric Convergence and Its Relationship with Extreme \\ Rainfall (Case Study: Cirebon Flood, February 15th, 2017)
}

\author{
Erwin Mulyana ${ }^{1)^{*}}$ \\ 1) Balai Besar Teknologi Modifikasi Cuaca - Badan Pengkajian dan Penerapan Teknologi, Gedung Ir. \\ Mohammad Soebagio, GEOSTECH (820), Kawasan PUSPIPTEK, Serpong, Tangerang Selatan \\ *E-mail: erwin.mulyana@bppt.go.id
}

\begin{abstract}
Intisari
Telah dilakukan analisis kondisi atmosfer di berbagai lapisan ketinggian untuk melihat keterkaitannya dengan kejadian hujan ekstrim di wilayah perbatasan Jawa Barat-Jawa Tengah pada tanggal 15 Februari 2017. Area penelitian difokuskan di area $108.0^{\circ}-109.5^{\circ}$ BT dan $6.5^{\circ}-7.5^{\circ}$ LS yang merupakan area hujan ekstrim (AHE). Analisis sebaran dan waktu kejadian hujan menggunakan data GSMaP dengan resolusi $0.1^{\circ} \times 0.1^{\circ}$ dan periode setiap satu jam, data satelit MERRA2 dengan resolusi $0.625^{\circ} \times 0.5^{\circ}$ dengan periode setiap 3 jam, data Radiosonde stasiun Cengkareng jam 07.00 dan 19.00 WIB, serta citra satelit Himawari 8. Hujan di wilayah AHE berlangsung pada jam 13.00-23.00 WIB dengan puncak hujan terjadi pada jam 18.00 WIB. Saat terjadi hujan ekstrim, terdapat perlambatan angin baratan di wilayah AHE serta adanya pertemuan angin dari utara dan dari selatan di wilayah tersebut. Area AHE merupakan area dengan konvergensi kuat pada level ketinggian $925 \mathrm{mb}$ dan $850 \mathrm{mb}$, sebaliknya terjadi divergensi pada level ketinggian $700 \mathrm{mb}$ dan $500 \mathrm{mb}$. Data Radiosonde menunjukkan kelembapan udara dari permukaan hingga lapisan $400 \mathrm{mb}$ umumnya lebih dari 80\%. Freezing level pada jam 07.00 WIB terdapat di level $571 \mathrm{mb}$ (4.622 m) dan pada jam 19.00 WIB terdapat di level $585 \mathrm{mb}$ (4.820 m).
\end{abstract}

Kata Kunci: Hujan Ekstrim, Konvergensi, Angin.

\begin{abstract}
Have been analyzed of the atmospheric conditions at various altitudes in its relationship with extreme rainfall over West Java-Central Java border area on February 15th, 2017. The study area is focused on the $108.0^{\circ}-109.5^{\circ}$ East and 6.5 - $7.5^{\circ}$ South, which is the extreme rainfall area (AHE). The data used in this study are GSMaP hourly rainfall $\left(0.1^{\circ} \times 0.1^{\circ}\right)$, MERRA2 satellite three-hourly data $\left(0.625^{\circ} \times 0.5^{\circ}\right)$, Cengkareng Radiosonde data at $07.00 L T$ and $19.00 \mathrm{LT}$, and Himawari 8 Satellite imagery. The rainfall in the AHE area occurred at 13.00-23.00 LT, with the peak rainfall, occurred at $18.00 \mathrm{LT}$. The lower atmospheric westerly wind became slower over the AHE area, while the northerly and southerly wind converged at this area. The AHE area has a strong convergence at level $925 \mathrm{mb}$, and $850 \mathrm{mb}$, conversely divergence occurred at level $700 \mathrm{mb}$ and $500 \mathrm{mb}$. The Radiosonde data shows that the air humidity is generally more than $80 \%$ from the surface to $400 \mathrm{mb}$. The freezing level at $07.00 \mathrm{LT}$ found at $571 \mathrm{mb}(4,622 \mathrm{~m})$ while at $19.00 \mathrm{LT}$ found at $585 \mathrm{mb}(4,820 \mathrm{~m})$.
\end{abstract}

Keywords: Extreme Rain, Convergence, Wind.

\section{PENDAHULUAN}

Indonesia sebagai daerah tropis dan dikenal sebagai benua maritim merupakan zona konvergensi dalam sistem sirkulasi global atmosfer yang berasosisasi dengan aktivitas konvektif yang sangat tinggi (Ramage, 1968). Zona Intertropical Convergence Zone (ITCZ) yang melintang dari barat ke timur serta secara periodik bergeser beberapa derajat ke utara dan selatan ekuator merupakan contoh dari konvergensi atmosfer yang dibangkitkan oleh sirkulasi Hadley. Zona konvergensi tersebut merupakan daerah pusat pertumbuhan awan yang dapat mengakibatkan hujan lebat dan bisa berlangsung berhari-hari serta memicu terjadi banjir dan longsor di beberapa wilayah di Indonesia. Banjir termasuk bencana hidrometeorologi yang paling sering terjadi di Indonesia.

Pola hujan di Pulau Jawa merupakan pola monsunal dengan puncak musim hujan 
berlangsung pada bulan Desember - Februari (Aldrian \& Susanto, 2003, Chang et al., 2005). Kejadian hujan ekstrim di Indonesia berhubungan dengan aktivitas monsun dan MJO (Wu et al., 2007; Wu et al., 2013; Renggono, 2013). Secara global, hujan ekstrim diprediksi akan semakin meningkat frekuensi kejadiannya serta dengan intensitas yang semakin tinggi (Westra et al., 2013). Variasi hujan di Indonesia berhubungan dengan ENSO (Mulyana, 2002; McBride et al., 2003; Chang et al., 2004; Xu et al., 2004; Aldrian et al., 2007; Qian et al., 2010), Indian Ocean Dipole (Saji et al., 2003), dan Monsun (Qian et al., 2010).

Hujan ekstrim sangat berpotensi menimbulkan banjir besar maupun tanah longsor akibat kerusakan lingkungan. Dalam 10 tahun terakhir (2009-2018) terdapat 7.226 kejadian banjir di Indonesia dengan tingkat kerugian mencapai 1.1 triliun Rupiah.

Pada tanggal 15 Februari 2017 terjadi hujan ekstrim di wilayah perbatasan Jawa Barat dan Jawa Tengah yang meliputi wilayah Cirebon, Kuningan, Ciamis, Brebes, Tegal, dan Cilacap. Kejadian hujan tersebut mengakibatkan banjir besar di wilayah Cirebon dan sekitarnya. Ribuan rumah di 11 kecamatan di Kabupaten Cirebon dan Kota Cirebon diterjang banjir, dan juga sempat melumpuhkan jalur lalu lintas di jalan utama Pantura di wilayah Cirebon Timur. Akumulasi hujan selama 10 jam di wilayah banjir dan sekitarnya mencapai 100-125 mm (Mulyana, 2017).

Tulisan ini mencoba menganalisis kondisi atmosfer pada beberapa level ketinggian saat terjadi hujan ekstrim pada tanggal 15 Februari 2017 di kawasan sepanjang perbatasan Jawa Barat dan Jawa Tengah yang mengakibatkan banjir besar di wilayah Cirebon dan sekitarnya.

\section{METODE}

Berikut ini merupakan data yang digunakan dalam analisis tulisan ini:

(1) Data hujan GSMaP (Global Satelite Mapping of Precipitation) dengan resolusi $0.1^{0} \times 0.1^{0}$ setiap jam. Data hujan GSMaP merupakan data estimasi hujan dan digunakan untuk menganalisis sebaran serta waktu kejadian hujan.

(2) Data atmosfer per 3-jam hasil observasi satelit MERRA2 yang terdiri dari angin zonal (u) dan angin meridional (v), serta kelembapan udara $(\mathrm{RH})$ pada level ketinggian $1.000 \mathrm{mb}, 925 \mathrm{mb}, 850 \mathrm{mb}, 700$ $\mathrm{mb}, 500 \mathrm{mb}, 400 \mathrm{mb}, 300 \mathrm{mb}$, dan $250 \mathrm{mb}$. Data satelit MERRA2 memiliki resolusi $0.5^{0}$ latitude dan $0.625^{\circ}$ longitude. Analisis spasial dan temporal kejadian hujan serta keadaan atmosfernya menggunakan perangkat lunak GrADS (Grid Analysis and Display System).

\section{HASIL DAN PEMBAHASAN}

\subsection{Curah Hujan}

Analisis hujan difokuskan di area dengan koordinat $108.0^{0}-109.5^{\circ}$ BT dan $6.5^{\circ}-7.5^{\circ} \mathrm{LS}$ yang selanjutnya akan disebut sebagai AHE (Area Hujan Ekstrim), ditunjukkan dengan garis segi empat pada Gambar 1. Sebelum melanjutkan pembahasan mengenai kejadian hujan, penulis menyampaikan terlebih dahulu kriteria hujan menurut BMKG. Disebut hujan ringan apabila intensitasnya $1-5 \mathrm{~mm} / \mathrm{jam}$ atau 5$20 \mathrm{~mm} /$ hari. Hujan sedang apabila intensitasnya $5-10 \mathrm{~mm} / \mathrm{jam}$ atau $20-50 \mathrm{~mm} /$ hari. Hujan lebat apabila intensitasnya $10-20 \mathrm{~mm} / \mathrm{jam}$ atau $50-100$ $\mathrm{mm} /$ hari, sedangkan hujan sangat lebat atau hujan ekstrim apabila intensitasnya lebih dari 20 $\mathrm{mm} / \mathrm{jam}$ atau $100 \mathrm{~mm} /$ hari.

Hujan di Pulau Jawa pada tanggal 15 Februari 2017 cukup merata dengan intensitas ringan hingga sangat lebat memanjang dari barat hingga timur. Kejadian hujan lebat hingga sangat lebat (hujan ekstrim) terjadi di wilayah Jawa Barat bagian timur hingga Jawa Tengah bagian barat. Hujan ekstrim dengan intensitas lebih dari $100 \mathrm{~mm} /$ hari terkonsentrasi di daerah Cirebon, Kuningan, Ciamis, Brebes, dan Cilacap. Hujan ekstrim juga terpantau di daerah antara Semarang - Gunung Merapi - Gunung Lawu (Gambar 1.a). Analisis sepasial-temporal menunjukkan bahwa siang hari sekitar jam 14.00 WIB terpantau kejadian hujan tidak merata di wiayah Banten bagian selatan, Jawa Barat bagian timur, Jawa Tengah bagian barat dan di wilayah Semarang. Satu jam berikutnya, hujan mulai meluas dan intensitasnya meningkat tajam terutama di wilayah AHE dan wilayah sebelah selatan Semarang. Hujan masih terus berlangsung di wilayah Jawa Barat bagian timur hingga Jawa Tengah dengan sebaran yang semakin luas. Pada jam 17.00 WIB, hujan di wilayah AHE semakin meningkat intensitasnya dengan cakupan yang terus meluas, sedangkan hujan di sebelah selatan Semarang berangsur angsur intesitasnya mulai berkurang. Pada jam 18.00 WIB, intensitas hujan di wilayah AHE terus meningkat hingga mencapai $30 \mathrm{~mm} / \mathrm{jam}$ (Gambar 1.b). Peningkatan intensitas hujan juga terjadi di wilayah Jakarta hingga mencapai $30 \mathrm{~mm} / \mathrm{jam}$. Jam 18.00 WIB merupakan puncak kejadian hujan di wilayah AHE, hujan ekstrim terpantau di daerah Cirebon, Ciamis dan Selatan Jakarta dengan intensitas hujan lebih dari $30 \mathrm{~mm} / \mathrm{jam}$. Satu jam kemudian yaitu pada jam 19.00 WIB, intensitas hujan semakin berkurang di hampir seluruh wilayah kejadian hujan. Namun demikian untuk wilayah AHE, intensitas hujan masih di atas $20 \mathrm{~mm} / \mathrm{jam}$. 


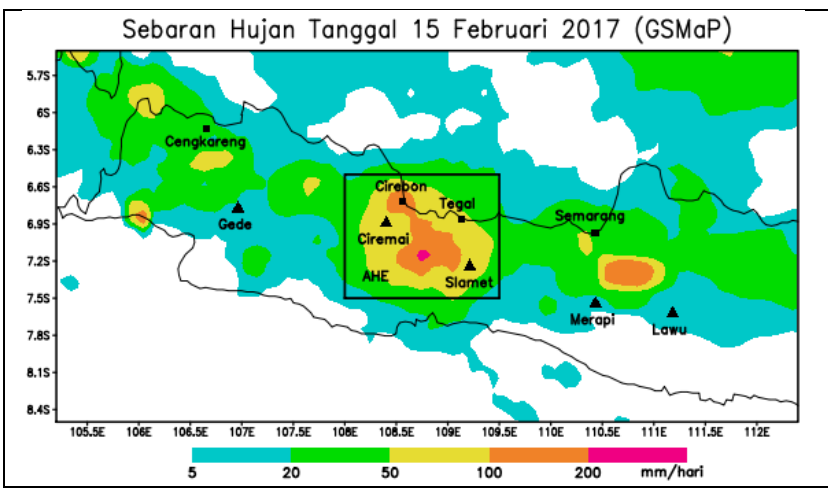

a.

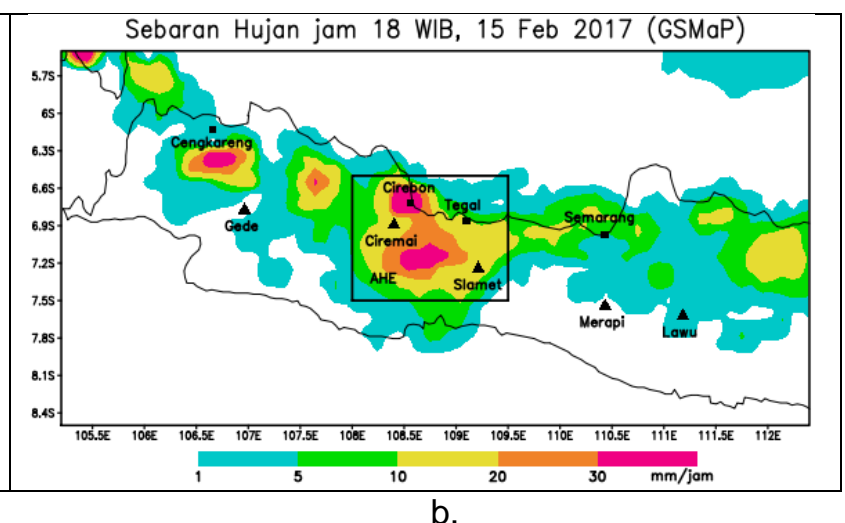

Gambar 1. (a.) Sebaran hujan harian di wilayah Jawa dan sekitarnya pada tanggal 15 Februari 2017, dan

(b.) sebaran hujan jam-jaman pada jam 16 WIB pada hari yang sama.

Berdasarkan rerata hujan wilayah AHE, hujan mulai turun pada jam 13.00 WIB (06Z) dengan intensitas ringan. Dua jam kemudian terjadi peningkatan hujan yang sangat sigifikan dan terus bertahan hingga 3 jam berikutnya. Pada jam 17.00 WIB hujan semakin deras dan terus meningkat hingga mencapai puncaknya pada jam 18.00 WIB. Selanjutnya intensitas hujan mulai berkurang hingga berhenti pada 00.00 WIB hari berikutnya. Perubahan intensitas hujan jam-jaman di wilayah AHE disajikan pada Gambar 2.

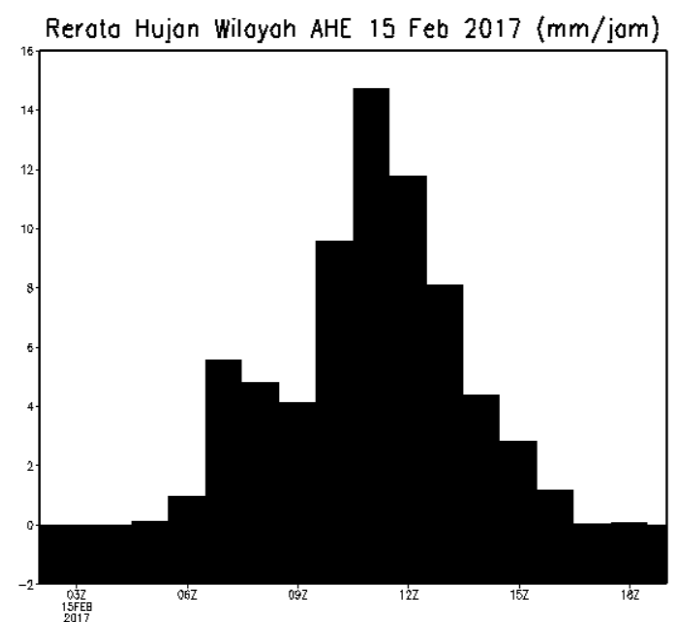

Gambar 2. Rerata hujan wilayah AHE pada tanggal 15 Februari 2017

\subsection{Arah dan Kecepatan Angin}

Pada saat kejadian hujan ekstrim pada tanggal 15 Februari 2017, angin di wilayah AHE umumnya bertiup dari arah barat laut, barat hingga barat daya. Angin dari Laut Cina selatan bergerak ke arah selatan dan berbelok menuju tenggara sebelum mencapai Jawa.

Sementara angin dari Samudra Hindia sebelah selatan Jawa Barat bertiup dari arah barat kemudian berbelok ke arah timur laut menuju wilayah AHE. Wilayah AHE dan sekitarnya merupakan daerah pertemuan angin dari barat laut dan dari barat daya. Kecepatan angin mengalami perlambatan ketika memasuki wilayah AHE dan sekitarnya. Kecepatan angin di Laut Jawa sebelah utara AHE mencapai $10 \mathrm{~m} / \mathrm{s}$, sementara di sebelah timur dan selatan AHE kecepatannya antara 6-8 m/s. Sedangkan di wilayah AHE dan sekitarnya kecepatannya 4-6 $\mathrm{m} / \mathrm{s}$. Sebaran arah dan kecepatan angin pada lapisan $925 \mathrm{mb}$ jam 13.00-19.00 WIB dapat dilihat pada Gambar 3.

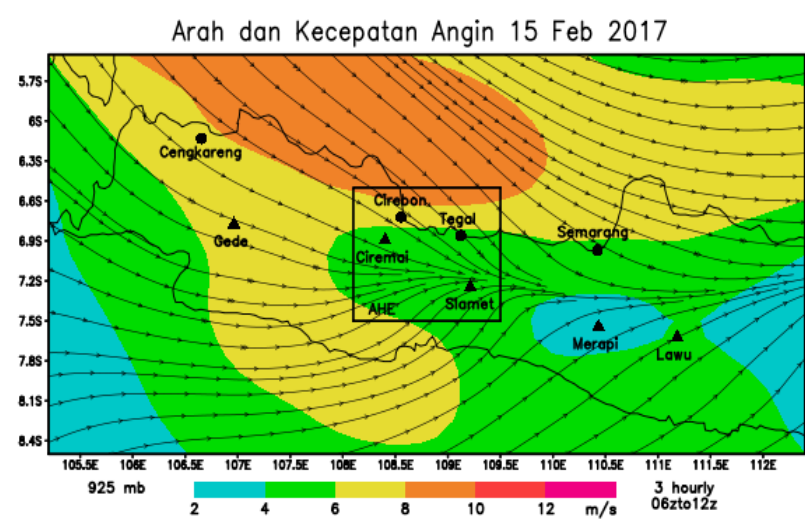

Gambar 3. Arah dan kecepatan angin tanggal 15 Februari 2017 jam 13.00-19.00 WIB pada lapisan $925 \mathrm{mb}$.

Komponen angin arah timur-barat (zonal wind) menunjukkan adanya perlambatan kecepatan angin baratan di wilayah AHE. Perlambatan angin baratan yang masuk ke wilayah AHE mulai berlangsung dari jam 13.00 WIB. Kondisi ini mengakibatkan terjadinya penumpukan massa udara di wilayah tersebut. Sementara komponen angin arah utara-selatan (meridional wind) menunjukkan bahwa wilayah AHE merupakan daerah pertemuan angin dari arah utara dan dari arah selatan. Adanya perlambatan kecepatan angin baratan di wilayah AHE ditambah dengan adanya pertemuan angin dari utara dan dari selatan, menjadikan wilayah AHE merupakan area konvergensi (Gambar 4). 


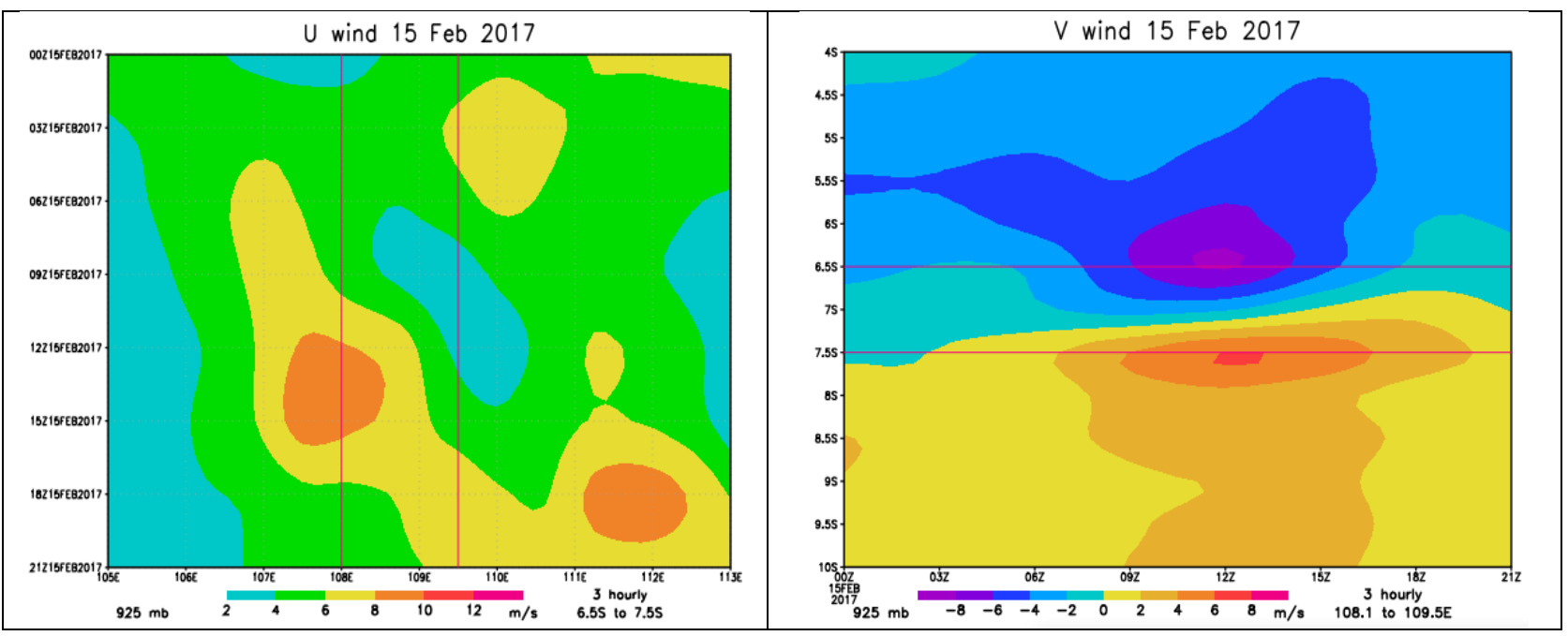

Gambar 4. Diagram Hovmoller angin zonal (kiri) dan angin meridional (kanan).

\subsection{Radiosonde}

Informasi atmosfer bagian atas diperoleh dari hasil pengukuran Radiosonde di Stasiun Pengamatan Cengkareng (6.110 LS, $106.65^{\circ} \mathrm{BT}$, 8 mdpl) pada tanggal 15 Februari 2017 jam 07.00 WIB dan 19.00 WIB. Pengamatan radiosonde di Cengkareng dipilih dengan pertimbangan jarak yang paling dekat dengan lokasi kejadian hujan ekstrim. Pertimbangan lain karena angin yang berhembus ke wilayah hujan ekstrim bertiup dari arah barat - barat laut, maka asumsinya massa udara yang masuk ke wilayah AHE memiliki sifat fisis yang relatif sama dengan massa udara di lokasi peluncuran Radiosonde. Gambaran profil vertikal atmosfer lapisan atas di Stasiun Pengamatan Cengkareng dapat dilihat pada Gambar 5 dan Tabel 1.
Profil vertikal hasil pengukuran dengan radiosonde pada pagi dan malam hari menunjukkan bahwa angin bertiup dari barat mulai dari permukaan hingga ketinggian sekitar $500 \mathrm{mb}$. Selanjutnya pada level di atasnya, arah angin berbalik menjadi dari timur hingga ketinggian $100 \mathrm{mb}$. Pada malam hari secara umum kecepatan angin baratan relatif lebih tinggi dibandingkan pada pagi hari. Kelembapan udara mulai dari permukaan hingga ketinggian $400 \mathrm{mb}$ pada pagi dan malam hari umumnya lebih dari 80 $\%$. Namun pada pagi hari ditemukan adanya lapisan udara cukup kering pada level ketinggian 600 - 550 mb dengan kelembapan 50 - 60\%. Freezing level $\left(0^{\circ} \mathrm{C}\right)$ pada jam 07.00 WIB berada pada level ketinggian $571 \mathrm{mb}$ atau 4.820 meter, sedangkan pada jam 19:00 WIB berada pada level $585 \mathrm{mb}$ atau 4.622 meter.

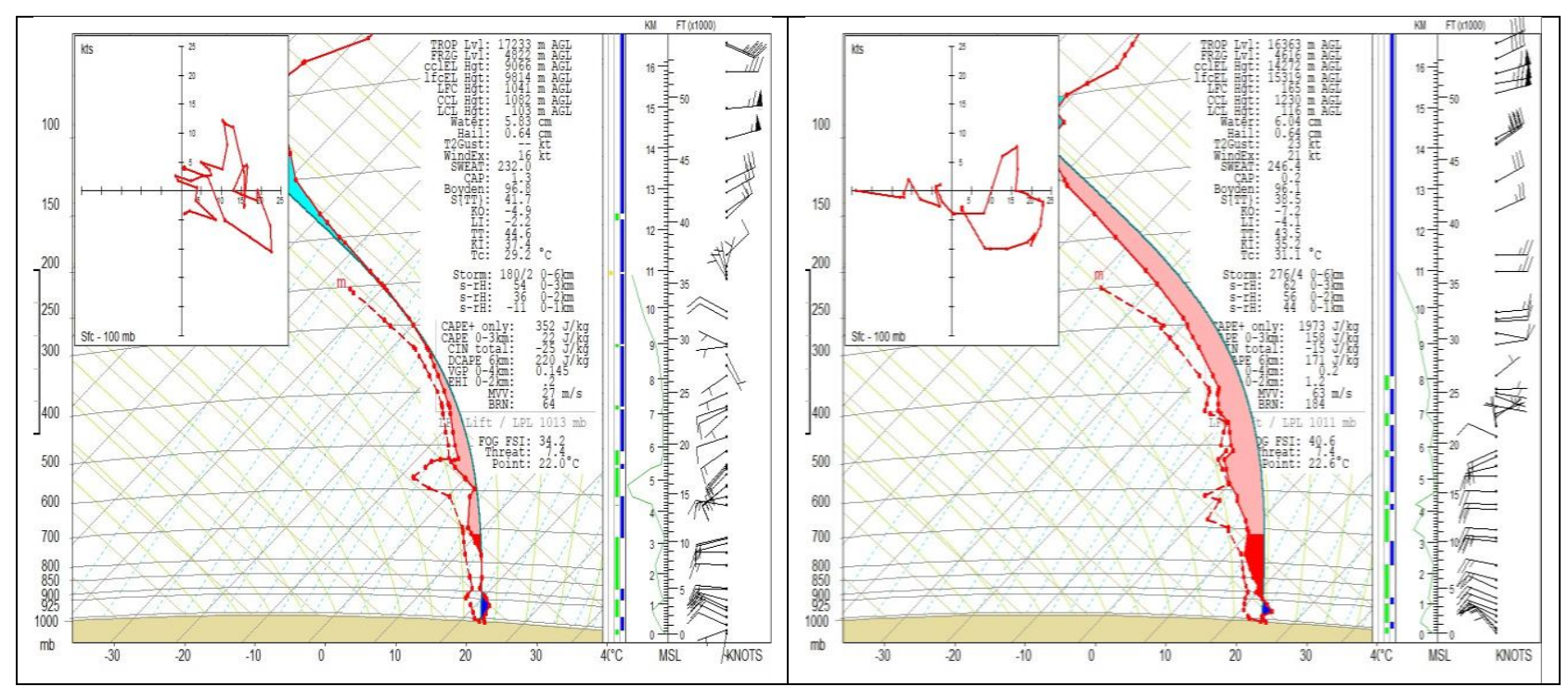

Gambar 5. Grafik hasil sounding Radiosonde di Stasiun Meteorologi Cengkareng pada tgl 15 Februari 2017 jam 07.00 WIB (kiri) dan 19.00 WIB (kanan). 
Tabel 1. Hasil Pengukuran Atmosfer Atas dengan Radiosonde di Stasiun Meteorologi Cengkareng Jam 07.00 WIB dan 12.00 WIB.

\begin{tabular}{|r|r|r|r|r|r|r|r|r|r|r|r|}
\hline \multicolumn{10}{|c|}{ Radiosonde Sta. Cengkareng (6.11 LS; 106.65 BT), 15 Februari 2017} \\
\hline \multirow{2}{*}{ No } & Level & \multicolumn{2}{|c|}{ Ketinggian $(\mathrm{m})$} & \multicolumn{2}{|c|}{ Temperatur $\left({ }^{\circ} \mathrm{C}\right)$} & \multicolumn{2}{|c|}{ Kelembaban $(\%)$} & \multicolumn{2}{|c|}{ Arah $\left({ }^{\circ}\right)$ dan Kec. Angin (knot) } \\
\cline { 3 - 12 } & $(\mathrm{mb})$ & $07: 00$ & $19: 00$ & $07: 00$ & $19: 00$ & $07: 00$ & $19: 00$ & $07: 00$ & $19: 00$ \\
\hline 1 & 1000 & 115 & 106 & 23.2 & 24.8 & 91 & 87 & 250 & 7 & 320 & 13 \\
\hline 2 & 925 & 796 & 785 & 20.8 & 21.8 & 81 & 84 & 295 & 25 & 290 & 22 \\
\hline 3 & 850 & 1,525 & 1,516 & 17.0 & 17.2 & 88 & 91 & 275 & 19 & 295 & 22 \\
\hline 4 & 700 & 3,159 & 3,154 & 7.8 & 9.2 & 94 & 82 & 255 & 17 & 275 & 23 \\
\hline 5 & 500 & 5,870 & 5,870 & -6.3 & -5.3 & 93 & 89 & 235 & 14 & 245 & 14 \\
\hline 6 & 400 & 7,590 & 7,590 & -15.7 & -15.1 & 92 & 90 & 245 & 6 & 100 & 4 \\
\hline 7 & 300 & 9,710 & 9,700 & -30.1 & -29.5 & 73 & 72 & 300 & 10 & 85 & 12 \\
\hline 8 & 250 & 10,970 & 10,970 & -40.7 & -39.9 & - & 42 & 350 & 4 & 90 & 24 \\
\hline
\end{tabular}

\subsection{Konvergensi Atmosfer}

Untuk melihat area mana saja yang merupakan derah konvergensi, dilakukan analisis konvergensi berdasarkan angin zonal (u) dan angin meridional ( $v$ ) dengan menggunakan persamaan sebagai berikut:

$$
C=-\left[\frac{\partial u}{\partial x}+\frac{\partial v}{\partial y}\right]
$$

Dengan $C$ merupakan nilai konvergensi, $u$ angin zonal (timur-barat), $v$ angin meridional (utara-selatan), $\mathrm{x}$ jarak pengamatan arah timurbarat $\left(0.625^{\circ}\right)$, dan y jarak pengamatan arah utara-selatan $\left(0.5^{\circ}\right)$. Dari perhitungan tersebut terlihat bahwa untuk wilayah AHE pada lapisan $925 \mathrm{mb}$ merupakan area dengan konvergensi kuat. Konvergensi juga masih terjadi pada pada lapisan $850 \mathrm{mb}$ walaupun konvergensinya tidak sekuat pada level atmosfer di bawahnya. Sedangkan pada lapisan $500 \mathrm{mb}$ maupun lapisan $200 \mathrm{mb}$ tampak wilayah AHE dan sekitarnya merupakan area divergen (Gambar 6).

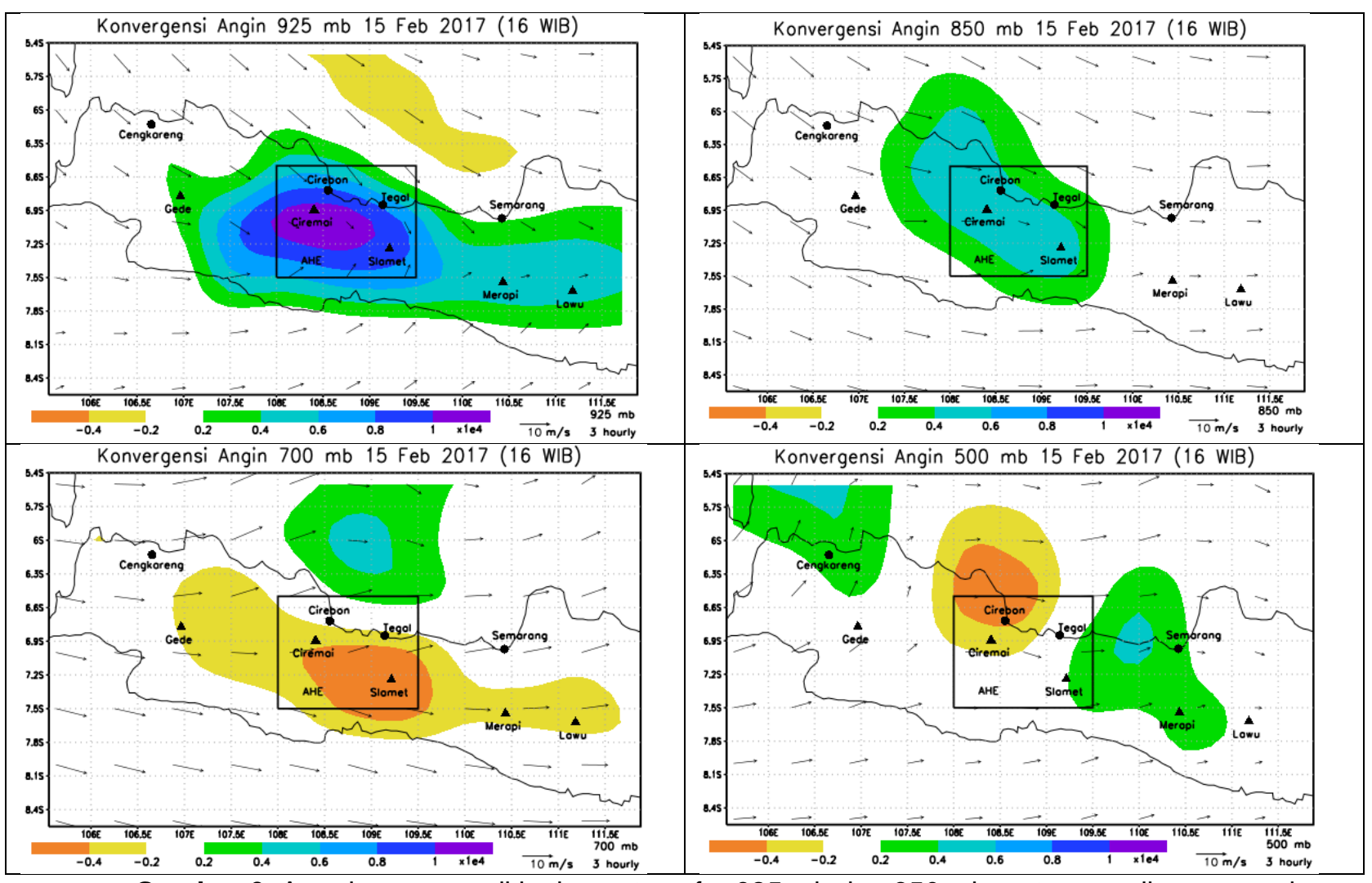

Gambar 6. Area konvergen di lapisan atmosfer $925 \mathrm{mb}$ dan $850 \mathrm{mb}$ serta area divergen pada lapisan di atasnya (700 mb dan $500 \mathrm{mb}$ ) di wilayah AHE. 
Adanya area konvergen di wilayah AHE pada lapisan atmosfer bawah memungkinkan terjadinya penumpukan udara lembap di wilayah tersebut. Massa udara yang terkumpul selanjutnya naik membentuk awan yang sangat besar dan lebar yang menimbulkan hujan ekstrim di kawasan. Citra satelit Himawari 8 pada jam 16.00 WIB memperlihatkan cluster awan tampak bersesuaian dengan daerah konvergensi (Gambar 7).

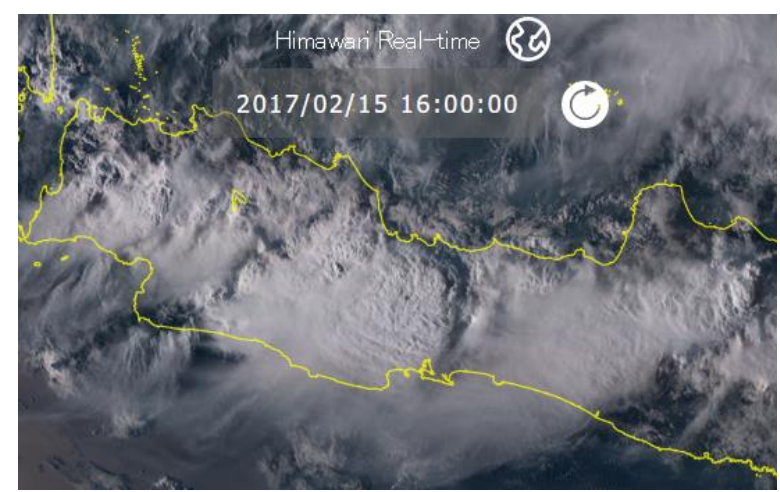

Gambar 7. Citra Satelit Himawari 8 kanal visible pada tanggal 15 Februari 2017 pukul 16.00 WIB yang menunjukkan area pembentukan awan bersesuaian dengan daerah konvergensi.

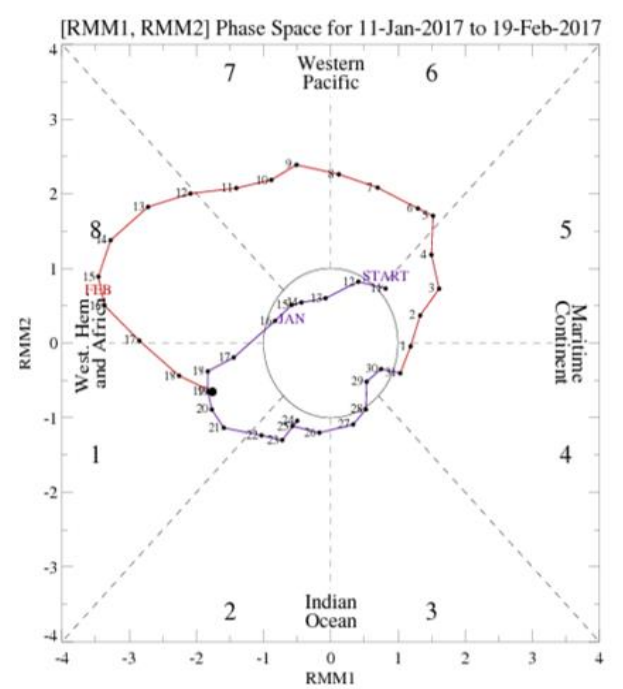

Gambar 8. Penjalaran MJO saat terjadi hujan ekstrim tgl 15 Februari 2018 berada pada fase 8 .

Berdasarkan data MJO (Madden-Julian Oscillation), selama pertengahan hingga akhir Januari 2017 daerah dengan aktivitas konvektif tinggi berada di wilayah Indonesia. Area konvektif tinggi ini terus bergeser ke timur namun masih dominan berada di wilayah Indonesia. Pada dasarian kedua bulan Februari 2017, aktivitas konvektif mulai berkurang untuk wilayah Sumatera, Jawa, Nusa Tenggara Barat hingga Nusa Tenggara Timur (Gambar 8).

MJO termasuk gangguan tropis yang bergerak ke arah timur di sekitar daerah tropis dengan siklus dalam 30-60 harian. MJO memiliki dampak luas pada pola curah hujan tropis dan subtropis, sirkulasi atmosfer, dan suhu permukaan di sekitar tropis dan subtropis. MJO juga dapat berkontribusi pada kecepatan perkembangan dan intensitas episode El Nino dan La Nina.

\section{KESIMPULAN DAN SARAN}

Dari pembahasan kondisi atmosfer di sekitar perbatasan Jawa Barat - Jawa Tengah saat kejadian banjir besar di Cirebon pada tangal 15 Februari 2017 dapat diambil kesimpulan sebagai berikut:

1. Hujan ekstrim pada tgl 15 Februari 2017 dengan intensitas lebih dari $100 \mathrm{~mm} /$ hari terkonsentrasi di daerah Cirebon, Kuningan, Ciamis, Brebes, dan Cilacap.

2. Wilayah hujan ekstrim merupakan area dengan perlambatan angin baratan serta area pertemuan angin dari Utara dan angin dari Selatan pada lapisan atmosfer bawah.

3. Wilayah hujan ekstrim merupakan area konvergen kuat pada lapisan atmosfer bawah, sebaliknya untuk lapisan atmosfer di atasnya merupakan area divergen.

4. Adanya konvergensi kuat pada lapisan atmosfer bawah serta didukung oleh udara basah memicu terjadinya hujan ekstrim di wilayah perbatasan Jawa Barat dan Jawa Tengah.

\section{DAFTAR PUSTAKA}

Aldrian, E., Susanto, R.D. (2003). Identification of Three Dominant Rainfall Region Within Indonesia and Their Relationship to Sea Surface Temperature. International Journal of Climatology, 23(12), 1435-1452. doi: 10.1002/joc.950

Aldrian, E., Gates, L.D., Widodo, F.H. (2007). Seasonal Variability of Indonesian Rainfall in ECHAM4 Simulations and in the Reanalyses: The Role of ENSO. Theoretical and Applied Climatology, 87, 41-59. doi: 10.1007/s00704-006-0218-8

Chang, C.P., Wang, Z., Ju, J., Li, T. (2004). On the Relationship between Western Maritime Continent Monsoon Rainfall and ENSO during Northern winter. Journal of Climate, 17(3), 665-672. doi: 10.1175/1520-

0442(2004)017<0665:OTRBWM>2.0.CO;2

Chang, C.P., Wang, Z., McBride, J., Liu, C.H. (2005). Annual Cycle of Southeast AsiaMaritime Continent Rainfall and the Asymmetric Monsoon Transition. Journal of Climate, 18(2), 287-301. doi: 10.1175/JCLI-3257.1

McBride, J.L., Haylock, M.R., Nicholls, N. (2003). Relationships between the Maritime Continent Heat Source and the El NiñoSouthern Oscillation Phenomenon. Journal of Climate, 16(17), 2905-2914. doi: 
$10.1175 / 1520-$

0442(2003)016<2905:RBTMCH >2.0.CO;2

Mulyana, E. (2002). Hubungan antara ENSO dengan Variasi Curah Hujan di Indonesia. Jurnal Sains \& Teknologi Cuaca, 3(1), 1-4.

Mulyana, E. (2017). Estimasi Volume Air Hujan pada saat Kejadian Banjir Cirebon Timur Tanggal 15-16 Februari 2017. Jurnal Sains dan Teknologi Mitigasi Bencana, 12(2), 11 18. doi: 10.29122/jstmb.v12i2.2134

Qian. J.H., Robertson, A.W., Moron, V. (2010). Interactions among ENSO, the Monsoon, and Diurnal Cycle in Rainfall Variability over Java, Indonesia. Journal of the Atmospheric Science, 67(11), 3509-3524. doi: 10.1175/2010JAS3348.1

Ramage, C.S. (1968). Role of a Tropical "Maritime Continent" in the Atmospheric Circulation. Monthly Weather Review, 96(6), 365-370.

Renggono, F. (2013). Analisis Hujan pada saat Banjir DKI dengan C-Band Radar. Jurnal Sains \& Teknologi Modifikasi Cuaca, 14(1), 51-58. doi: 10.29122/jstmc.v14i1.2682

Saji, N.H., Yamagata, T. (2003). Possible Impacts of Indian Ocean Dipole Mode Events on Global Climate. Climate
Reseach, 25(2), 151-169. doi: $10.3354 / \mathrm{cr} 025151$

Westra, S., Alexander, L.V., Zwiers, F.W. (2013). Global Increasing Trends in Annual Maximum Daily Precipitation. Journal of Climate, 26(11), 3904-3918. Doi: 10.1175/JCLI-D-12-00502.1

Wu, P., Hara, M., Fudeyasu, H., Yamanaka, M.D., Matsumoto, J., Syamsudin, F., Sulistyowati, R., Djajadihardja, Y.S. (2007). The Impact of Trans-equatorial Monsoon Flow on the Formation of Repeated Torrential Rains over Java Island. SOLA, 3, 93-96. doi: 10.2151/sola.2007-024

Wu, P., Arbain, A.A., Mori, S., Hamada, J.I., Hattori, M., Syamsudin, F., Yamanaka, M.D. (2013). The Effects of an Active Phase of the Madden-Julian Oscillation on the Extreme Precipitation Event over Western Java Island in January 2013. SOLA, 9, 79 - 83. doi: 10.2151/sola.2013018

Xu, Z.X., Takeuchi, K., Ishidaira, H. (2004). Correlation between El Niño-Southern Oscillation (ENSO) and Precipitation in South-East Asia and the Pacific Region. Hydrological Processes, 18(1), 107-123. doi: 10.1002/hyp.1315 